\title{
LINGUA
}

Jurnal Bahasa, Sastra dan Pengajarannya

Volume 14, No. 2, September 2017

\author{
Diterbitkan oleh: \\ PUSAT KAJIAN BAHASA DAN BUDAYA \\ CENTER OF LANGUAGE AND CULTURE STUDIES \\ SURAKARTA




\title{
LINGUA \\ Jurnal Bahasa, Sastra dan Pengajarannya
}

Terbit pertama kali pada September 2004 dengan nama CERTEL (p ISSN: 1829 9601).

Terbit dengan nama LINGUA pada Maret 2009 (p ISSN: 1979 9411).

Terbit online mulai Maret 2015 (e ISSN: 2442 238X).

Terbit dua kali setahun pada Maret dan September memuat artikel hasil penelitian atau kajian kepustakaan bidang bahasa, sastra, budaya dan pengajarannya. Artikel ditulis dalam bahasa Indonesia atau bahasa Inggris.

\author{
Ketua Penyunting \\ Teguh Budiharso \\ Wakil Ketua Penyunting \\ Mulkan Wahyudi \\ Penyunting Pelaksana \\ Umar Fauzan \\ Sekretaris \\ Sukmawan Wisnu Pradanta \\ Pelaksana Tatausaha \\ Rano Wandhana \\ Mitra Bebestari: \\ I. Gusti Astika, Universitas Satya Wacana Salatiga \\ Moh. Adnan Latief, Universitas Negeri Malang \\ Wahyudi Siswanto, Universitas Negeri Malang \\ Moh. Harun, Universitas Syiah Kuala, Banda Aceh \\ Asnawi Muslem, Universitas Syiah Kuala, Banda Aceh \\ Junaidi Mistar, Universitas Islam Malang \\ Ignatius Harjanto, Universitas Widya Mandala, Surabaya \\ Sujito, IAIN Surakarta \\ Imroatus Solikhah, IAIN Surakarta \\ Umar Fauzan, IAIN Samarinda \\ Lalu Suhirman, Universitas Cenderawasih, Papua
}

\begin{abstract}
Alamat Penyunting dan Tatausaha: J1. Samosir No. 23 Rt 002 Rw 011 Margorejo, Kelurahan Gilingan, Kecamatan Banjarsari, Surakarta 57134 dan Greenville Residence Blok A 11 12 Rt 002 Rw 004, Jl. Mangesti Raya, Kelurahan Mayang, Kecamatan Gatak, Kabupaten Sukoharjo, Jawa Tengah. HP. 081334455566; Http://lingua.pusatbahasa.or.id, Email: presslingua@gmail.com Langganan dua nomor setahun Rp 75.000 termasuk ongkos kirim. Bank Mandiri No. Rek. 138000 0001516.

LINGUA, Jurnal Bahasa, Sastra dan Pengajarannya diterbitkan oleh PUSAT KAJIAN BAHASA DAN BUDAYA (Center of Language and Culture Studies) Surakarta. Akta Notaris Drs. Irwan Siregar, SH, M.Kn Nomor 5 Tanggal 21 Januari 2015; SK Menkumham RI Nomor: AHU 0000276.AH.01.07. Tahun 2015 tanggal 26 Pebruari 2015.

Redaksi menerima tulisan yang belum pernah diterbitkan dalam media cetak lain. Naskah diketik dalam spasi rangkap pada kertas quarto, panjang 12 20 halaman (lihat Petunjuk Bagi Penulis). Naskah dikirim via email dalam format Windows. Naskah yang masuk disunting oleh Penyunting Ahli, bila diterima naskah bisa diubah untuk keseragaman format. Naskah yang dimuat dikenakan ongkos cetak.
\end{abstract}




\section{INDEKS LINGUA}

LINGUA: Jurnal Bahasa, Sastra dan Pengajarannya (p ISSN: 1979 9411, e ISSN: 2442 238X) yang diterbitkan oleh Pusat Kajian Bahasa dan Budaya (Center of Language and Culture Studies), Surakarta saat ini terindeks di Moraref, OCLC Worldcat, Indonesia OneSearch, Google Scholar.

\section{Google}

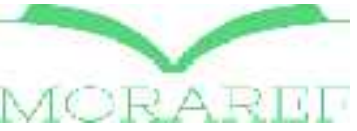

Onesearch SW WorldCat

C IEJD

(4) 용 


\section{DAFTAR ISI}

Frasa dan Klausa dalam Kata Polisintesis pada Bahasa Tolaki

Ilfan Askul Pehala, Universitas Sebelas Maret

127-140

Etika Pengembaraan Ilmu Masyarakat Jawa pada Naskah Serat

Dewa Ruci Karya R. Ng. Yasadipura I dalam Perspektif Kehidupan Modern

Edy Suprayitno, STKIP PGRI Ponorogo

Struktur Instrinsik Novel Kepanggang Wirang Tiwiek SA dan Implikasinya

dalam Pembelajaran Bahasa Jawa di SMA

Rhian Ardila Maretin Lanua, Kundharu Saddhono \& Supana

Universitas Sebelas Maret

155-180

Kajian Asinonimitas Al-Kitab Wal Al-Qur'an: Qira'ah Muashirah

Mia Fitriah Elkarimah, Universitas Indraprasta PGRI (UNINDRA)

Karakter dalam Preman, Antologi Cerkak Karya Tiwiek SA dan Implikasinya

terhadap Pembelajaran Bahasa Jawa

Galih Dwi Purboasri, Kundharu Saddhono \& Suyitno

Universitas Sebelas Maret

Upacara Kematian Saur Matua Batak Toba: Analisis Tradisi Lisan

Relly Monika Hasugian, Universitas Sumatera Utara

Kajian Stilistika pada Tajuk Rencana Surat Kabar Harian Umum Haluan

Nur Aini Syah, Universitas Sebelas Maret

Proses Morfofonemik dalam Bahasa Jepang

Sari Suti H. Nasution, Universitas Sumatera Utara

Pemilihan Kode pada Mahasiswa Riau di Yogyakarta: Kajian Sosiolinguistik

Juni Mahsusi, Djatmika \& Sri Marmanto

Universitas Sebelas Maret

Gaya Bahasa dalam Penggalan Novel Pudarnya Pesona Cleopatra

Karya Habiburrahman El-Zhirazy

Qurratul A’ini, Universitas Sebelas Maret

Frasa Adjektiva Bahasa Jepang: Analisis X-bar

Puti Novianti Aristia, Universitas Sumatera Utara

295-308

Perbedaan antara Klausa Subordinatif Bahasa Indonesia dan Bahasa Inggris

Anisak Syaid Fauziah, Mustofa Kamal, Djatmika, Sumarlam

Universitas Sebelas Maret

309-324 